\title{
Spatial temporal analysis of mortality by suicide among the elderly in Brazil
}

Emelynne Gabrielly de Oliveira Santos' Yonara Oliveira Monique da Costa Oliveira ${ }^{2}$ Ulicélia Nascimento de Azevedo ${ }^{2}$ Aryelly Dayane da Silva Nunes² Ana Edimilda Amador ${ }^{2}$ Isabelle Ribeiro Barbosa ${ }^{3}$

\section{Abstract}

Objective: to perform spatiotemporal analysis of suicide mortality in the elderly in Brazil. Methods: a mixed ecological study was carried out in which deaths from suicide among the elderly were analyzed using data from the Mortality Information System (MIS) and socio-demographic variables, from 2000 to 2014, with a trend analysis of this period. Univariate and bivariate spatial analysis was performed using the Moran Global and Moran Map index to evaluate the intensity and significance of spatial clusters. Results: there were 19,806 deaths due to suicide among the elderly in Brazil between 2000 and 2014. The ratio of male and female mortality rates was $4: 1$, with increasing trends for both genders $\left(\mathrm{R}^{2}>0.8\right)$, but with greater intensity among men $(p=0.0293)$. There was a moderate autocorrelation for men ( $\mathrm{I}>0.40)$, with clusters forming for both genders in the south of Brazil. Bivariate analysis showed the formation of clusters in the southern region with the Human Development Index and aging variables and in the north and northeast regions based on dependence and illiteracy ratio. Conclusions: mortality due to suicide among the elderly has a tendency to increase and is unequally distributed in Brazil.

\section{Keywords: Suicide.} Elderly. Mortality. Social Determinants of Health. Spatial Analysis.

\footnotetext{
Universidade Federal do Rio Grande do Norte (UFRN), Programa de Pós-graduação em Saúde Coletiva, Faculdade de Ciências da Saúde do Trairi (FACISA). Santa Cruz, RN, Brasil.

2 Universidade Federal do Rio Grande do Norte (UFRN), Programa de Pós-graduação em Saúde Coletiva, Centro de Ciências da Saúde. Natal, RN, Brasil.

3 Universidade Federal do Rio Grande do Norte, Faculdade de Ciências da Saúde do Trairi (FACISA). Santa Cruz, RN, Brasil. 


\section{INTRODUCTION}

Population aging is a growing concern in developing countries due to the rapid demographic changes that have occurred in recent years. In Brazil, the growth of the elderly population, both in absolute and proportional terms, is increasingly significant. The effects of this increase are already a reality and can be perceived in social needs and in the areas of health and social security ${ }^{1}$.

According to data from the Instituto Brasileiro de Geografia e Estatística (the Brazilian Institute of Geography and Statistics) (IBGE) ${ }^{2}$, the Brazilian elderly population was $14,235,731$ in the year 2000 , with the projection for the year 2030 some 41,541,763 individuals. The proportion of individuals aged 60 years or older presents an upward trend in Brazil, due to higher life expectancy and better access to goods and services that assist in the aging process ${ }^{3}$.

Highly devitalizing situations are also observed during the aging process, with the frequent underlying impairment of mental health, leading to depression, which can often determine the occurrence of suicidal thoughts and/or the execution of suicide itself $f^{4}$. It is believed that two-thirds of suicides in the elderly population are related to depression ${ }^{5}$. The large number of suicides in the elderly population is notable among the causes of deaths in this population group, and is considered a global public health problem ${ }^{6}$.

Risk factors for geriatric suicide can be medical - such as chronic and disabling diseases, recurrent hospitalization and frequent surgeries, psychiatric and/or psychological factors; and family-related factors, such as the loss of family ties, intrafamily violence and the impact of changes and losses ${ }^{7,8}$.

There is no single explanation for suicide, with the interaction of various factors such as social, psychological and cultural elements, as well as suicide attempts, constituting an important risk factor ${ }^{6}$. The manifestation of suicidal behavior in the elderly is different from in other age groups. Its signs are more difficult to detect, and more lethal methods, nonimpulsive acts and passive suicide, such as abstaining from eating, are involved?

Suicide rates for both genders present large regional and socioeconomic disparities in all regions of the world. A study with elderly people in Portugal showed that those with inferior socioeconomic conditions and greater dependence had greater suicidal ideation'. In the USA, a sample of urban and non-urban areas between 1999 and 2015 found that rates increased since 2000, and were higher in nonurban areas throughout the period ${ }^{10}$. In Brazil, suicide rates are low compared to most countries, ranging from 3.50 to $5.80 / 100,000$ inhabitants. However, the rates for elderly people, understood as individuals aged 60 years or over, are twice those of the general population, and there are differences between the states of the country over time ${ }^{11,12}$.

Some social and political initiatives that ensure the right to health of the elderly have been implemented, including the Statute of the Elderly (2003) $)^{13}$ and the National Policy on the Health of the Elderly $(2006)^{14}$. More specific actions have focused on suicide prevention, such as the National Policy for the Reduction of Morbidity and Mortality by Accidents and Violence $(2000)^{15}$, the National Strategy for Suicide Prevention (2006) ${ }^{16}$, and initiatives of the Ministry of Health, which aim to reduce the rates of death by suicide and harm caused to those directly and indirectly involved in this act.

To understand this phenomenon, it is important to consider ecological studies that analyze contextual factors related to suicide mortality. In addition, the monitoring of mortality trends over the years and knowledge of the geographical distribution of suicide are of great importance for the planning and evaluation of prevention policies, with the possibility of identifying areas of greater vulnerability and the development of more effective strategies for populations at risk. It is worth highlighting studies that analyze the different forms of spatial organization of society in the Brazilian urban network, among them the Urban Articulation Regions, areas defined by the IBGE, which conceptually include the reduction of social inequalities, preserving the cultural, environmental and economic diversity that exists within the country ${ }^{17}$.

In view of the magnitude and complexity of suicide in the elderly population, the objective of this study was to perform a spatial-temporal analysis of suicide mortality in the elderly in the Immediate Urban Articulation Regions (IUAR) of Brazil. 


\section{METHOD}

A mixed ecological study was performed which analyzed the mortality by suicide of individuals aged 60 years or older between January 1, 2000 and December 31, 2014, according to the 482 Immediate Urban Articulation regions (IUAR) in Brazil.

Deaths from self-inflicted injuries, according to the individual's age group and gender, were categorized according to the International Statistical Classification of Diseases and Related Health Problems - $10^{\text {th }}$ Revision (X60-84). Data on deaths were collected from the Mortality Information System (MIS) of the Department of Informatics of the National Health System (Datasus).

The crude mortality rates were calculated by year and by gender, adjusted by the direct method according to the world population and expressed per 100,000 inhabitants per year ${ }^{18}$. Population data by IUAR, by gender and by age group were obtained from the Demographic Censuses and Inter-Census Projections information on the IBGE website. To analyze mortality trends by gender, the standardized mortality rates for 2000 to 2014 were analyzed by the linear regression method, evaluated by the coefficient of determination $\left(\mathrm{R}^{2}\right)$. The level of significance was $95 \%$.

To analyze the Moran Local and Global spatial statistics, the Mean Suicide Standardized Mortality Ratio (SMR) was calculated by quinquennium and by gender. Spatial dependence analysis was performed using the Moran Global index, estimating the spatial autocorrelation, which can vary between -1 and +1 , in addition to providing the statistical significance ( $p$-value). After the general analysis, the presence of clusters was evaluated through Moran Local (Local Indicators of Spatial Association - LISA). Therefore, the MoranMap for suicide mortality rates was constructed, including only those clusters with a value of $p<0.05$. For validation of the Moran Global Index, the random permutation test with 99 permutations was used ${ }^{19}$. For the production of thematic maps in quintiles and the calculation of the
Local and Global Moran Index, the Terraview 4.2.2 (INPE, 2011, Tecgraf PUC-Rio/FUNCAT, Brazil) software was used.

Based on the SMR for the five-year period from 2010 to 2014, bivariate spatial statistical analysis was applied and was considered the dependent variable. The independent variables, represented by the socioeconomic indicators of Brazilian municipal regions, were: (a) Municipal Human Development Index (M-HDI); (b) Dependency ratio; (c) Aging rate; (d) Illiteracy rate of people aged 25 years and over; (e) Gini index; (f) Unemployment rate of people aged 18 years and over. Socioeconomic indicators for the year 2010 were collected from the Atlas of Human Development of Brazil of the United Nations Development Program (UNDP).

Bivariate LISA analysis was performed with GeoDa 1.6.61 software (Spatial Analysis Laboratory, University of Illinois, Urbana Champaign, USA) to evaluate the spatial correlation between the outcome variable (suicide standardized mortality rates) and the independent variables. To do this, thematic maps were constructed with each pair of variables and the spatial dependence pattern and its statistical significance.

This research used secondary data available on official websites of the Department of Health of Brazil without the identification of subjects, and as such was exempt from evaluation by an ethics research committee, in accordance with Resolution 466/2012 of the National Health Council.

\section{RESULTS}

From 2000 to 2014, there were 19,806 suicide deaths in Brazil. Of these, 40.37\% $(n=7,998)$ occurred in the period from 2010 to 2014 . The average mortality rate for suicide in the elderly registered in Brazil for the years 2010 to 2014 was 1,149 deaths per 100,000 inhabitants. The highest average rates observed in the period studied were 1,740/100,000 inhabitants for men and 0.452/100,000 inhabitants for women, which occurred between 2010 and 2014 (Table 1). 
Table 1. Descriptive analysis of socioeconomic indicators and Suicide Standardized Mortality Ratio (100,000 inhab.), according to gender. Immediate Urban Articulation Regions of Brazil, 2000-2014.

\begin{tabular}{llllllll}
\hline Variables & Minimum & Maximum & Mean & Median & $\begin{array}{l}\text { Standard } \\
\text { Deviation }\end{array}$ & $\begin{array}{l}\text { Percentile } \\
25\end{array}$ & $\begin{array}{l}\text { Percentile } \\
75\end{array}$ \\
\hline SMR 2000-2004 women & 0.000 & 5.720 & 0.310 & 0.060 & 0.628 & 0.000 & 0.360 \\
\hline SMR 2005-2009 women & 0.000 & 4.780 & 0.326 & 0.090 & 0.566 & 0.000 & 0.440 \\
\hline SMR 2010-2014 women & 0.000 & 4.760 & 0.452 & 0.170 & 0.731 & 0.000 & 0.530 \\
\hline SMR 2000-2004 men & 0.000 & 13.79 & 1.211 & 0.780 & 1.402 & 0.310 & 1.610 \\
\hline SMR 2005-2009 men & 0.000 & 8.400 & 1.490 & 1.140 & 1.417 & 0.530 & 1.940 \\
\hline SMR 2010-2014 men & 0.000 & 9.360 & 1.740 & 1.260 & 1.489 & 0.690 & 2.340 \\
\hline SMR both genders 2010-2014 & 0.000 & 5.35 & 1.149 & 0.850 & 0.962 & 0.457 & 1.594 \\
\hline Gini & 0.361 & 0.670 & 0.497 & 0.495 & 0.052 & 0.463 & 0.532 \\
\hline Unemployment (\%) & 0.824 & 18.355 & 6.100 & 5.767 & 2.961 & 4.153 & 7.729 \\
\hline HDI & 0.477 & 0.774 & 0.660 & 0.675 & 0.065 & 0.601 & 0.712 \\
\hline Dependence (\%) & 36.761 & 86.628 & 51.466 & 48.645 & 8.297 & 45.190 & 56.555 \\
\hline Aging & 2.320 & 15.356 & 8.244 & 8.309 & 2.204 & 6.831 & 9.762 \\
\hline Illiterate (\%) & 2.731 & 49.904 & 19.931 & 15.340 & 12.022 & 10.044 & 31.029 \\
\hline
\end{tabular}

Source: Mortality Information System (MIS); Atlas Brasil, 2013. SMR: Standardized Mortality Rate. HDI: Human Development Ratio

The ratio of male to female mortality rates was 4:1. The growth of the standardized mortality rate throughout the historical sequence analyzed for both sexes was observed with a statistically significant trend. The slope of the line, equivalent to the Effect
Index, is ascending. On average, the coefficient was 0.0293 in SMR per 100,000 inhabitants with a variation of $88 \%$ in men, and 0.0096 in SMR per 100,000 inhabitants and a variation of $80 \%$ in women (Figure 1).

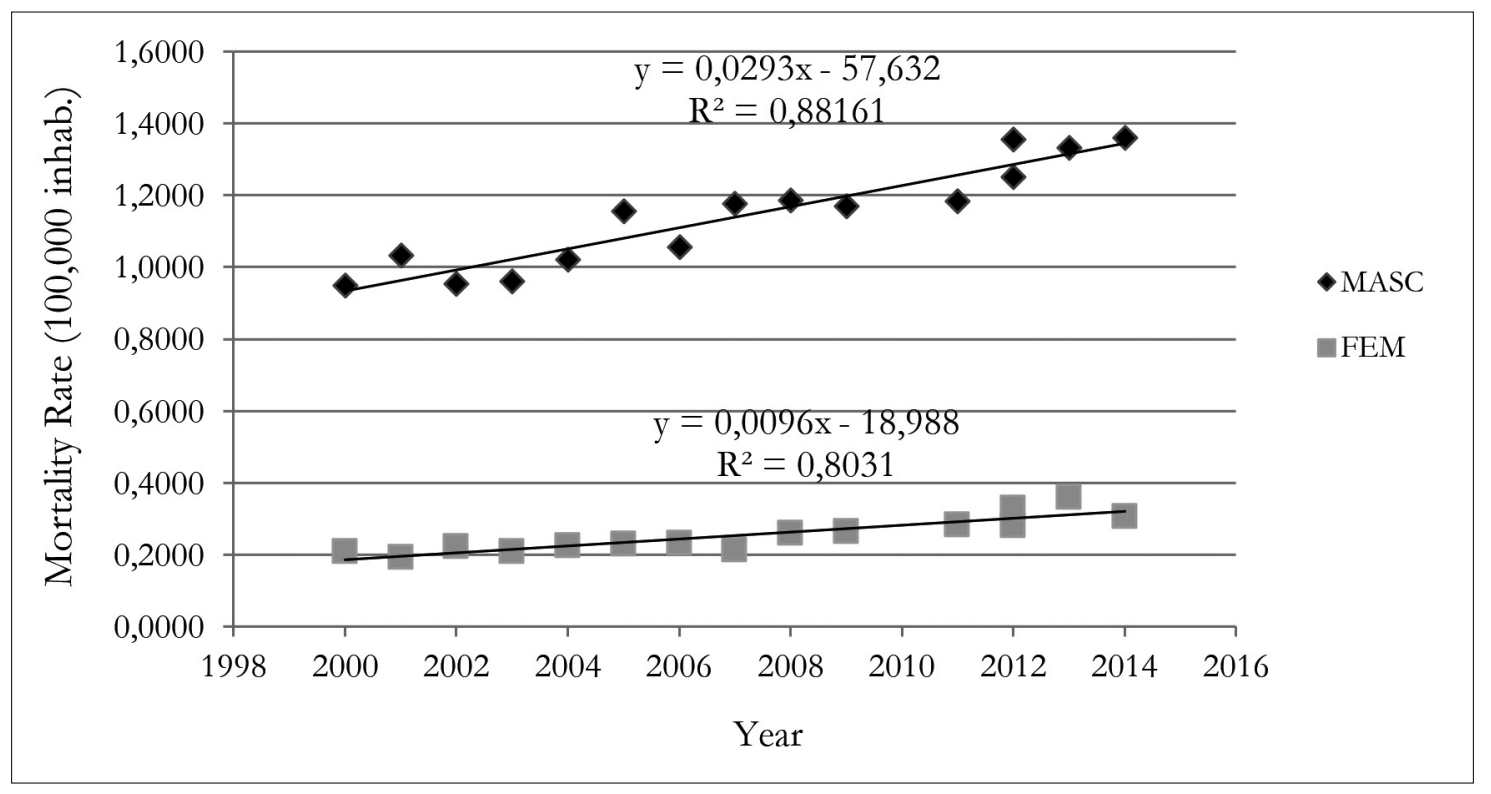

Source: Mortality Information System (MIS).

Figure 1. Analysis of temporal trend of mortality due to suicide in the elderly, according to gender. Brazil, 2000 to 2014. 
No spatial autocorrelation was observed for SMR due to suicide in elderly women in Brazil. The Moran Global value obtained exhibited a weak spatial autocorrelation, although this value was statistically significant. For the male population, however, a spatial autocorrelation of suicide mortality was observed in the three quinquennia analyzed, highlighting the increase in mortality rates due to suicide in men in the northeast region over the fiveyear period (Figure 2).

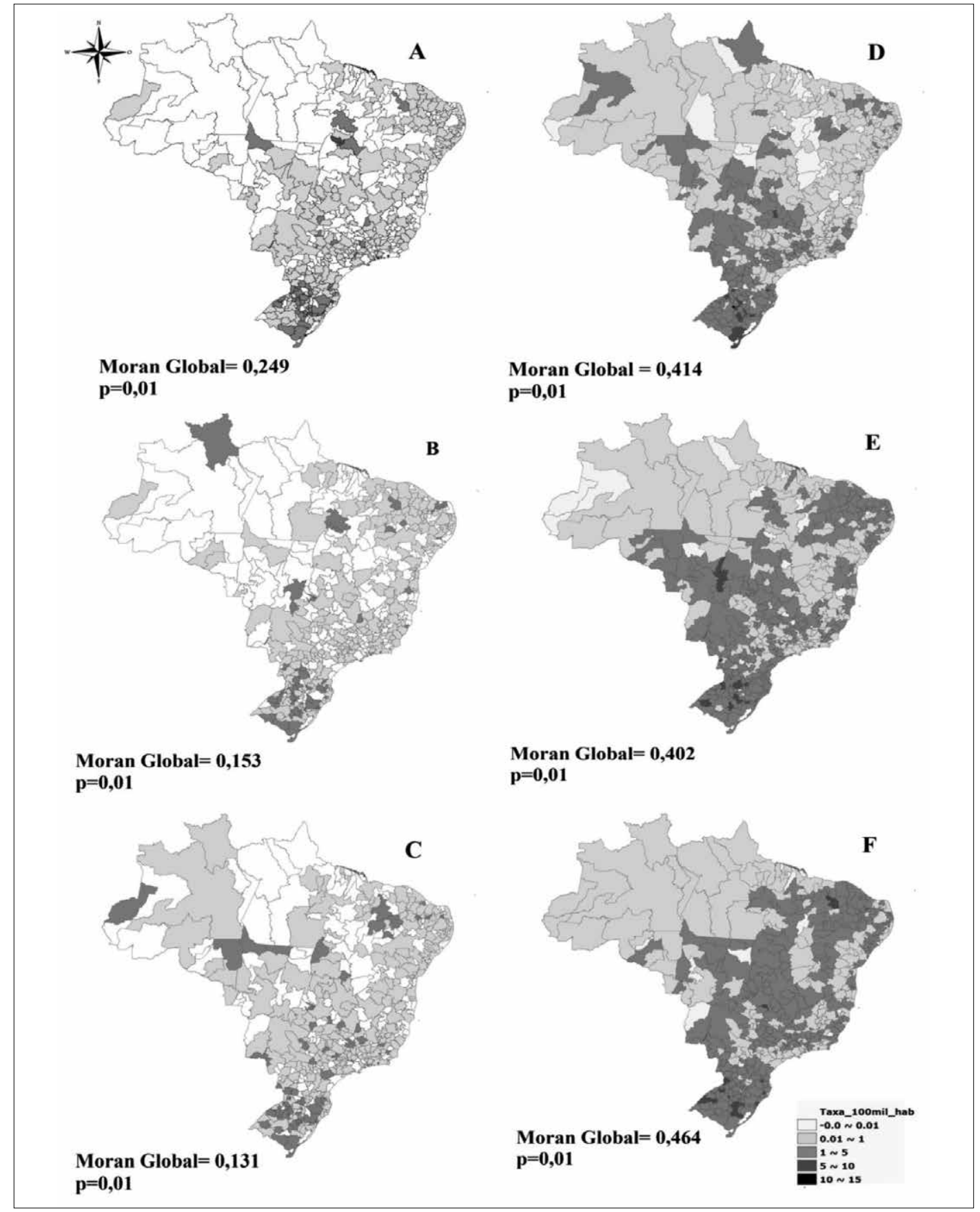

Figure 2. Spatial distribution of Standardized Mortality Rate (SMR) by suicide according to gender in Brazil and respective Moran Global values. 2A: SMR for women in the period 2000-2004; 2B: SMR for women in the 2005-2009 period; 2C: SMR for women in the period 2010-2014; 2D: SMR for men in the period 2000-2004; 2E: SMR for men in the 2005-2009 period; 2F: SMR for men in the period 2010-2014. 
MoranMap analysis revealed the presence of clusters with high mortality rates in the south of the country, especially among men. In the north, meanwhile, there are clusters of low mortality rates (Figure 3).

Bivariate spatial analysis with Bivariate Moran autocorrelation between the studied socioeconomic variables and SMR due to suicide in the elderly (Figure 4). However, the formation of clusters of high SMR in the south of Brazil was observed, with high HDI values and aging rate. For the dependency and illiteracy variables clusters with high SMR levels were found in northeast Brazil (Figure 4).

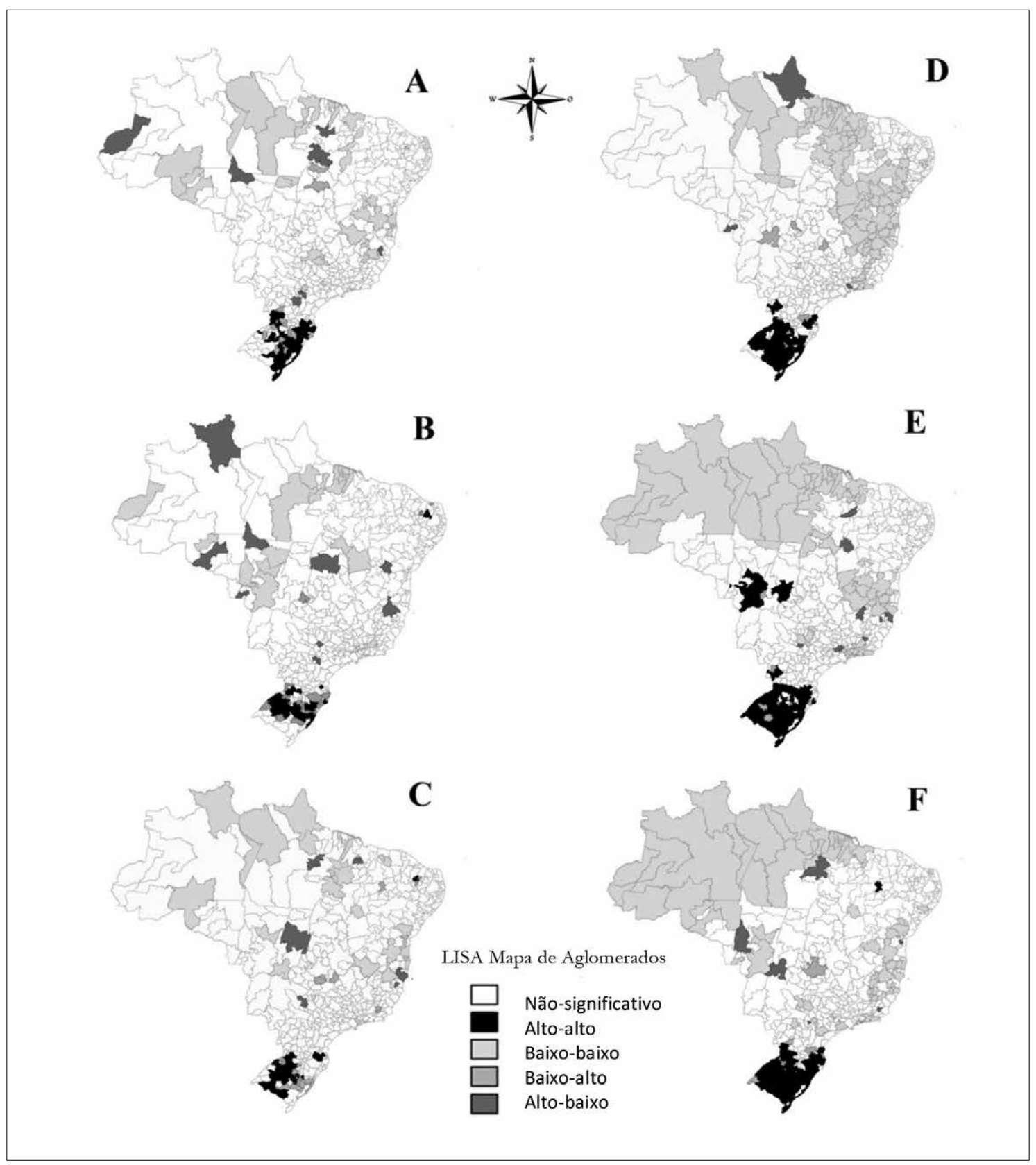

Figure 3. MoranMap of Standardized Mortality Rate (SMR) by suicide in Brazil according to gender and quinquennia. 3A: MoranMap of SMR for women in period 2000-2004; 3B: MoranMap of SMR for women in period 2005-2009; 3C: MoranMap of SMR for women in period 2010-2014; 3D: MoranMap of SMR for men in period 2000-2004; 3E: MoranMap of SMR for men in period 2005-2009; 3F: MoranMap of SMR for men in period 2010-2014. 


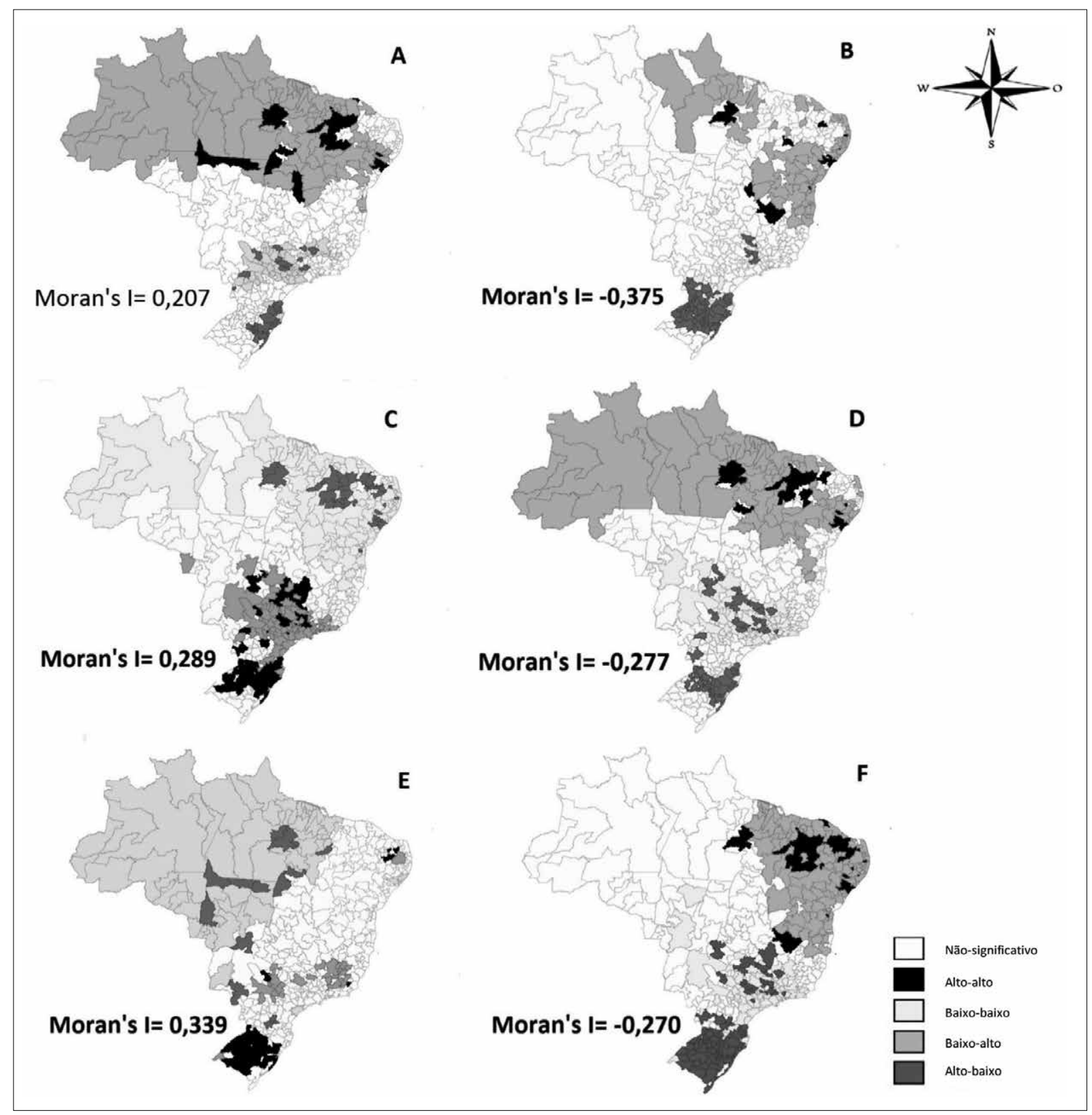

Figure 4. Moran bivariate LISA (Moran's I) between Standardized Suicide Mortality Rates in the period 20102014 for both genders and the socioeconomic variables of the Immediate Urban Articulation Regions. 4A: GINI; 4B: Unemployment rate; 4C: HDI; 4D: Dependency Ratio; 4E: Aging; 4F: Illiteracy.

Source: Mortality Information System (MIS); Atlas Brasil, 2013.

\section{DISCUSSION}

In the present study, the mortality rate due to suicide in the elderly presented a statistically significant increasing trend for both genders in the study period, with higher rates for men and marked geographical inequality in distribution.
This trend of suicide rates in the elderly population, especially among men, has already been reported in Brazil in a study by Minayo et al. ${ }^{20}$, which evaluated the trend of suicide in the elderly population in Brazil and Rio de Janeiro in the period 1980-2006, and also found an increase in the rates of suicide among the elderly, with a rise from 595.3 deaths/year in 1980 to 7.994 
deaths/year in 2006, with the same ratio of 4 male deaths to 1 female death by suicide in 2006. A study on suicide mortality in the elderly in Brazilian municipal regions in the period 1996-2007 12 showed that more than half of the municipal regions had deaths by this cause, with rates rising in the last triennium analyzed (2005-2007), with a mortality male/female ratio of 2.8 , increasing to $4: 1$ in $25 \%$ of cases.

While suicide mortality rates among the elderly in Brazil are still considered low on a global scale, the growth trend is worrying. The $\mathrm{WHO}$ considers the increase in the deaths of the elderly in relation to 50 years ago when there was little variation due to age to be notable ${ }^{20,21}$.

There are consistent data in literature that indicate higher rates of suicide in all age groups for men ${ }^{21-24}$. In old age, when professional life ends, many men associate the new phase of their lives with the loss of their traditional role of economic provider and head of family, and withdraw socially, leading to a high risk of isolation, sadness, stress and the desire to end their life. Situations of social isolation and loneliness mainly affect men, becoming, in their case, a risk factor for suicide ${ }^{23}$.

When the spatial distribution of standardized rates of death by suicide in the elderly were analyzed, no spatial patterns were observed in distribution among women. Among men, however, the formation of two well defined clusters was noted: a region of high rates in the south of Brazil and another region of low rates in the north of the country. Despite not forming statistically significant clusters, the increase in mortality rates by suicide among the elderly over time in the northeast region was noted. Similar results were found in a study that evaluated the spatial distribution of suicide in Brazil in the general population, with clusters of high mortality rates in the south of the country, with no significant spatial autocorrelation values and no association with the socioeconomic factors analyzed ${ }^{25}$. Similar results were also found in a study of the spatial distribution of suicide mortality in the northeast of Brazil, which was found to be random, without the formation of clusters when associated with the socioeconomic factors analyzed ${ }^{26}$.

Suicide rates show great variation between different countries and within the countries themselves, which is a reflection of the complexity of this phenomenon. In this context, in a country like Brazil with more than 200 million inhabitants and regions with different socioeconomic and cultural characteristics, the heterogeneous distribution of suicide mortality rates is expected ${ }^{27}$. Historically, the states of the south of the country, specifically Rio Grande do Sul, have the highest suicide rates, with an average of 10.2/100,000 inhabitants in 1980-1999 ${ }^{28}$. Pinto et al. ${ }^{12}$ evaluating suicide among the elderly in Brazilian municipal regions, also pointed out that the regions with the highest rates are concentrated in the south of the country, especially in Rio Grande do Sul. Ethnic origin (descendants of Europeans), culture, social crises and even the climatic aspects of the region have been suggested as possible causes ${ }^{28}$.

Suicide is a complex phenomenon, and therefore can be investigated through an individual approach, where psychological, psychiatric variables and incapacitating clinical conditions are analyzed, along with the social context in which the phenomenon occurs, through sociodemographic variables ${ }^{24}$. Since the mid-nineteenth century, researchers have attempted to understand the temporal and geographic variations of suicide. One of the most important studies in this area was that carried out in France by Durkheim at the end of the nineteenth century. Using mortality statistics, this researcher analyzed suicide as a collective phenomenon, based on its social causes. According to his theory, social integration and regulation protect individuals from suicide. $\mathrm{He}$ postulates that there are therefore higher rates of suicide in urban regions among more educated people and individuals without companions ${ }^{29,30}$.

In the present study, bivariate spatial analysis between the standardized suicide mortality rates of elderly persons and sociodemographic variables was performed in order to better understand the geographic distribution of suicide rates among the elderly in Brazil and the possible influence of social context on this event. The influence of social and economic factors was observed when comparing the southern region of the country, traditionally an area with higher rates of suicide and which is more economically developed, with the north and northeast regions, which have low suicide rates and unfavorable socioeconomic indicators.

There was a weak and direct spatial autocorrelation between suicide mortality rates in the elderly and the 
Gini, HDI and Aging indexes, with clusters of high suicide SMR with high HDI and aging in the south of the country, showing that the problem persists even under more favorable socioeconomic conditions. For the unemployment rate, dependency ratio and illiteracy variables, the spatial correlation was weak and negative, with the formation of clusters of the low-high type in the north and northeast regions, revealing that suicide rates remained low in an area of unfavorable social and economic indicators. Factors such as social inequality, low income and unemployment, as well as schooling, influence the occurrence of suicide. One possible explanation is that socioeconomic status promotes different patterns of life with different levels of exposure to environmental risk factors and access to resources, including behavioral and psychosocial factors such as perceived violence, feelings of deprivation and stress. In this way, economic factors influence the health of the individual, including their mental health ${ }^{31}$.

Most of the studies that investigate this issue have been carried out in Europe and other equally wealthy countries, such as the USA and Japan, and there is little knowledge of the influence of these factors on suicide rates in South America, especially in Brazil, a country that is known to have an unequal society.

This study has limitations, such as the impossibility of transposing the results obtained at the ecological level to the individual level, a limit of the type of study employed; the quality of records in suicide

\section{REFERENCES}

1. Oliveira ATRD. Envelhecimento populacional e políticas públicas: desafios para o Brasil no século XXI. Espaço Econ. 2016;4(8):2-21.

2. Instituto Brasileiro de Geografia e Estatística, Coordenação de População e Indicadores Sociais. Síntese de indicadores sociais: uma análise das condições de vida da população brasileira: 2016. Rio de Janeiro: IBGE; 2016.

3. Andrade LM, Sena ELS, Pinheiro GML, Meira EC, Lira LSSP. Políticas públicas para pessoas idosas no Brasil: uma revisão integrativa. Ciênc Saúde Coletiva [Internet]. 2013 [acesso em 26 abr. 2017];18(12):3543-52. Disponível em: http://www.scielo.br/scielo.php?script $=$ sci_ arttext\&pid=S1413-81232013001200011\&lng=en mortality information systems, where it is recognized that this event is still underreported, and the fact that there may be regional differences in the quality of these records. In order to overcome fluctuations in suicide rates that could lead to erroneous conclusions, in this study it was decided to use IUAR to evaluate the distribution of this phenomenon in Brazil.

\section{CONCLUSIONS}

The present study, which used an ecological approach with spatial analysis methods, found that suicide in the Brazilian elderly population has been increasing in recent years, especially in males, and that this event is unevenly distributed, reflecting socioeconomic differences between regions with high and low suicide rates. Although suicide is a complex and multifactorial phenomenon, the ecological approach combined with spatial distribution analysis makes it possible to identify how it manifests itself in different population groups, showing how the social environment can affect the health of the population, and is particularly useful to identify areas of risk and thus the most appropriate planning of interventions. More detailed studies are needed, especially in regions of greater risk, so that a more complete analysis of the factors that can influence the increase of death by suicide of the elderly in Brazil can be carried out, allowing the planning of interventions that reduce the impact of these deaths, which are considered to be preventable and unnecessary.

4. Sousa GSD, Silva RMD, Figueiredo AEB, Minayo MCDS, Vieira LJEDS. Circunstâncias que envolvem o suicídio de pessoas idosas. Interface (Botucatu) [Internet]. 2014 [acesso em $24 \mathrm{fev}$. 2017];18(49):389-402. Disponível em: http://www. scielo.br/scielo.php?script $=$ sci_arttext\&pid $=$ S141432832014000200389\&lng $=$ en

5. Cavalcante FG, Minayo MCS, Mangas RMN. Diferentes faces da depressão no suicídio em idosos. Ciênc Saúde Coletiva [Internet]. 2013 [acesso em 03 fev. 2017];18(10):2985-94. Disponível em: http://www. scielo.br/scielo.php?script $=$ sci_arttext\&pid=S1413$81232013001000023 \& \operatorname{lng}=$ en 
6. World Health Organization. Preventing Suicide: a Global Imperative. Geneva: WHO; 2014.

7. Barrero SAP. Suicide risk factors among the elderly. Ciênc Saúde Coletiva [Internet]. 2012 [acesso em 03 fev. 2017];17(8):2011-6. Disponível em: http://www. scielo.br/scielo.php?script=sci_arttext\&pid=S1413$81232012000800012 \& \operatorname{lng}=$ en

8. Cavalcante ACS, Servio SMT, Franco FRA, Cunha VP, Cavalcante FV, Nascimento CEM. A clínica do idoso em situação de vulnerabilidade e risco de suicídio. Trivium [Internet]. 2015 [acesso em 20 fev. 2017];7(1):74-87. Disponível em: http://www.uva.br/ trivium/edicoes/ano

9. Almeida L, Quintão S. Depressão e iIdeação suicida em idosos institucionalizados e não institucionalizados em Portugal. Acta Med Port [Internet]. 2012 [acesso em 05 mar. 2017];25(6):350-8. Disponível em: https://run.unl. pt/bitstream/10362/21667/1/1351-2001-1-PB.pdf

10. Kegler SR, Stone DM, Holland KM. Trends in suicide by level of urbanization — United States, 1999-2015. MMWR Morb Mortal Weekly Rep [Internet]. 2017 [acesso em 10 maio 2017];66(10):270-3. Disponível em: https://www.cdc.gov/mmwr/volumes/66/wr/ mm6610a2.htm

11. Carvalho ILN, Lôbo APA, Aguiar CAA, Campos AR. A intoxicação por psicofármacos com motivação suicida: uma caracterização em idosos. Rev Bras Geriatr Gerontol [Internet]. 2017 [acesso em 15 maio 2017];20(1):129-37. Disponível em: http://www. redalyc.org/articulo.oa?id=403850707014_2

12. Pinto LW, Assis SG, Pires TO. Mortalidade por suicídio em pessoas com 60 anos ou mais nos municípios brasileiros no período de 1996 a 2007. Ciênc Saúde Coletiva [Internet]. 2012 [acesso em 03 maio 2017];17(8):1963-72. Disponível em: http://www.scielo.br/scielo.php?script=sci_ arttext\&pid=S1413-81232012000800007\&lng=en

13. Brasil. Lei no 10.741 de $1^{\circ}$ de Outubro de 2003. Dispões sobre o Estatuto do idoso e dá outras providências. Diário Oficial da União. 3 de out. 2003. p. 1.

14. Brasil. Portaria n 2.528 de 20 de outubro de 2006. Aprova a Política Nacional de Saúde da Pessoa Idosa. Saúde Legis. 2006.

15. Brasil. Ministério da Saúde, Secretaria de Políticas de Saúde.Política Nacional de Redução da Morbimortalidade por Acidentes e Violência. Rev Saúde Pública. 2000; 34(4):427-30.

16. Brasil. Portaria No 1.876 , de 15 de agosto de 2006. Institui Diretrizes Nacionais para Prevenção do Suicídio, a ser implantadas em todas as unidades federadas, respeitadas as competências das três esferas de gestão. Saúde Legis. 2006.
17. Instituto Brasileiro de Geografia e Estatística. Diretoria de Geociência, Coordenação de Geografia. Divisão Urbano-Regional. [sem local]: IBGE; 2013.

18. Doll R, Payne P, Waterhouse JAH, editors. Cancer incidence in five continents. Vol. I. Geneva: Union Internationale Contre le Cancer; 1966.

19. Anselin L. Local indicators of spatial association. Geogr Anal. 1995;27(2):93-115.

20. Minayo MCDS, Pinto LW, Assis SGD, Cavalcante FG, Mangas RMDN. Tendência da mortalidade por suicídio na população brasileira e idosa, 1980-2006. Rev Saúde Pública [Internet]. 2012 [acesso em 10 maio 2017];46(2):300-9. Disponível em: http://www.scielo.br/scielo.php?script $=$ sci_ arttext\&pid=S0034-89102012000200012\&lng=en

21. World Health Oragnization. World Report on Violence and Health. Genève: WHO; 2002.

22. Pinto LW, Assis SG. Estudo descritivo das tentativas de suicídio na população idosa brasileira, 2000- 2014. Ciênc Saúde Coletiva [Internet]. 2015 [acesso em 30 Abr 2017];20(6):1681-92. Disponível em: http://www.scielo.br/scielo.php?script $=$ sci_ arttext\&pid=S1413-81232015000601681\&lng=en

23. Minayo MCS, Meneghel SN, Cavalcante FG. Suicídio de homens idosos no Brasil. Ciênc Saúde Coletiva [Internet]. 2012 [acesso em 12 mar. 2017];17(10):2665-74. Disponível em: http://www. scielo.br/scielo.php?script $=$ sci_arttext\&pid=S1413 81232012001000016\&lng=en

24. Bezerra Filho JG, Werneck GL, Almeida RLF, Oliveira MIV, Magalhães FB. Estudo ecológico sobre os possíveis determinantes socioeconômicos, demográficos e fisiográficos do suicídio no Estado do Rio de Janeiro, Brasil, 1998-2002. Cad Saúde Pública [Internet]. 2012 [acesso em 14 fev. 2017];28(5):833-44. Disponível em: http://www. scielo.br/scielo.php?script $=$ sci_arttext\&pid=S0102311X2012000500003\&lng=en

25. Dantas APQ, Azevedo UM, Nunes ADS, Amador AE, Marques MV, Barbosa IR. Analysis of suicide mortality in Brazil: spatial distribution and socioeconomic context. Rev Bras Psiquiatr [Internet]. No prelo 2017. Disponível em: http://www.scielo. br/scielo.php?script $=$ sci_arttext\&pid $=$ S151644462017005014104\&lng=en

26. Oliveira ES, Barbosa IR. Conglomerados espacias da mortalidade por suicídio no nordeste do Brasil e sua relação com indicadores socioeconômicos. Cad Saúde Coletiva [Internet]. 2017 [acesso em 09 nov. 2017];25(3):371-8. Disponível em: http://www. scielo.br/scielo.php?script=sci_arttext\&pid $=$ S1414462X2017000300371\&lng=en 
27. Bando DH, Brunoni AR, Benseñor IM, Lotufo PA. Suicide rates and income in São Paulo and Brazil: a temporal and spatial epidemiologic analysis from 1996 to 2008. BMC Psychiatry [Internet]. 2012 [acesso em 30 abr. 2017];12(4 Suppl 1):432-5. Disponível em: https://bmcpsychiatry.biomedcentral.com/ articles/10.1186/1471-244X-12-127

28. Meneghel SN, Victora CG, Faria NMX, Carvalho LA, Falk JW. Características epidemiológicas do suicídio no Rio Grande do Sul. Rev Saúde Pública [Internet]. 2004 [acesso em 15 maio 2017];38(6):804-10. Disponível em: http://www. scielo.br/scielo.php?script $=$ sci_arttext\&pid $=$ S003489102004000600008\&lng=en
29. Durkheim E. O suicídio: estudo sociológico. São Paulo: Martins Fontes; 2000.

30. Bando DH, Moreira RS, Pereira JC, Barrozo LV. Spatial clusters of suicide in the municipality of São Paulo 1996-2005: an ecological study. BMC Psychiatry [Internet]. 2012 [acesso em 13 abr. 2017];12(1):124. Disponível em: https://bmcpsychiatry.biomedcentral. com/articles/10.1186/1471-244X-12-124

31. Machado DB, Dos Santos DN. Suicídio no Brasil, de 2000 a 2012. J Bras Psiquiatr [Internet]. 2015 [acesso em 27 jan. 2017];64(1):45-54. Disponível em: http://www.scielo.br/scielo.php?script $=$ sci_ arttext\&pid=S0047-20852015000100045\&lng=en.

Received: July 25, 2017

Reviewed: October 26, 2017

Accepted: November 14, 2017 